\title{
Isolasi Cendawan Aspergillus sp. pada Tanaman Padi Organik
}

\author{
The Isolation of Fungus Aspergillus sp on Organic Rice Plant
}

\author{
Author(s): Nor Imama Iga Mawarni ${ }^{(1) *}$; Iqbal Erdiansyah ${ }^{(1)}$; Rudi Wardana ${ }^{(1)}$ \\ (1) Politeknik Negeri Jember \\ * Corresponding author: iqbal@polije.ac.id
}

\begin{abstract}
ABSTRAK
Penelitian bertujuan agar dapat mengidentifikasi karakteristik cendawan Aspergillus sp. secara makroskopis, jumlah koloni, kecepatan tumbuh cendawan dan kepadatan spora cendawan Aspergillus sp. yang telah diisolasi dari dua lokasi berbeda. Penelitian ini Aspergillus sp., dilakukan dari September 2019 hingga November 2019. Metode penelitian yang digunakan adalah metode survey, yaitu dengan membandingkan cendawan Aspergillus sp yang dapat diisolasi dari 2 lahan yang berbeda. Data dari hasil penelitian yang diperoleh kemudian dianalisis secara kualitatif dan kuantitatif. Hasil penelitian menunjukkan bahwa dari kedua lokasi pengambilan sampel tanah pada lokasi pertama jamur Aspergillus sp. dapat diisolasi lokasi pada kedalaman 20-25 cm dari permukaan tanah. Sedangkan di lokasi kedua, jamur pengambilan Aspergillus sp. dapat diisolasi pada kedalaman 10-15 cm dan 20-25 cm dari permukaan sampel tanah. tanah dan memiliki karakteristik morfologi berupa koloni berwarna hitam, hifa bersekat, konidia bulat, konidiofor tegak dan tidak bercabang serta vesikel yang berbentuk bulat. Kemudian untuk jumlah koloni cendawan Aspergillus sp. yang dapat diisolasi dari Desa Lombok Kulon dan Desa Sulek menunjukkan hasil yang berbeda nyata. Sedangkan untuk kecepatan pertumbuhan dan nilai kepadatan spora cendawan Aspergillus sp. dari kedua lokasi menunjukkan hasil yang berbeda tidak nyata.
\end{abstract}

\section{Keywords:}

Aspergillus sp., depth level, soil sampling.

\section{ABSTRACT}

This study aimed to identify the characteristics of Aspergillus sp. macroscopically, the number of colonies, growth speed, and spore density of Aspergillus sp. had been isolated from two different locations. This research was conducted from September to November 2019. The research method used was a survey method, namely by comparing the fungus Aspergillus sp, which can be isolated from 2 different fields. The obtained data were analyzed qualitatively and quantitatively. The results showed that in the first location, fungus Aspergillus sp. could be isolated at 20-25 cm depth from the ground level. Whereas in the second location, Aspergillus sp. could be isolated at $10-15 \mathrm{~cm}$ and 20-25 cm depth from the ground level, and it had morphological characteristics such as black colonies, hyphae insulated, round conidia, upright and unbranched conidiophores, and rounded vesicle. Then for the number of colonies Aspergillus sp. that isolated from Lombok Kulon and Sulek villages showed significantly different results. While for the growth speed and density value of the fungus Aspergillus sp. from the two locations showed insignificantly different results. 


\section{PENDAHULUAN}

Cendawan Aspergillus sp. merupakan salah satu jenis cendawan yang menguntungkan dalam dunia pertanian, salah satunya yaitu dapat dimanfaatkan sebagai agensia hayati. Cendawan Aspergillus sp. mampu menghasilkan metabolit sekunder. Metabolit sekunder merupakan senyawa metabolit primer yang telah melalui tahap biosintetik (Murniasih, 2003). Senyawa metabolit sekunder yang dapat dihasilkan oleh cendawan Aspergillus sp. salah satunya adalah tensyuic acid (Hasegawa et al., 2007). Senyawa metabolit sekunder tersebut dapat menjadikan cendawan Aspergillus Sp. sebagai agensia hayati karena bersifat antagonis terhadap penyakit yang menyerang tanaman budidaya. Cendawan Aspergillus sp. juga memiliki potensi untuk melarutkan unsur phospat dalam tanah dengan mensekresikan asam-asam organik, seperti asam format, asetat, propionat, laktat, glikolat, fumarat, dan suksinat sehingga dapat dimanfaatkan oleh tanaman dan juga dapat menjaga serta meningkatkan kualitas tanah. Berdasarkan potensinya tersebut maka cendawan Aspergillus $s p$. juga dapat dijadikan sebagai pengganti pupuk non-organik.

Cendawan Aspergillus sp. biasanya mudah ditemui di lahan-lahan dengan kualitas tanah yang baik, misalnya tanahtanah dengan kadar bahan organik yang tinggi. Berdasarkan hal tersebut budidaya tanaman secara organik tentunya sangat berpotensi untuk menjaga kualitas tanah serta menopang ketersediaan mikroorganisme menguntungkan di dalam tanah, salah satunya yaitu cendawan Aspergillus sp. Menurut Ariyono (2014), dalam penelitiannya menyebutkan bahwa, cendawan memang dapat diisolasi lebih banyak pada lahan yang menerapkan sistem pertanian organik. Isolasi cendawan yang dilakukan pada lahan dengan sistem pertanian organik menghasilkan 47 spesies cendawan dengan total 60 koloni, termasuk di dalamnya adalah cendawan Aspergillus sp. (Ariyono, 2014).

Cendawan Aspergillus sp. bisa didapatkan dengan cara isolasi dari daerah rhizosfer tanaman padi, karena cendawan bersimbiosis dengan akar tanaman. Adanya simbiosis antara cendawan dan akar tanaman dapat memberikan dampak yang cukup besar bagi pemenuhan nutrisi tanaman (Noerfitryani, 2018). Selain itu, bagi cendawan, daerah rhizosfer sangat mendukung untuk menjaga kelangsungan hidupnya, karena pada daerah rhizosfer terdapat nutrisi yang berasal dari sisa-sisa makhluk hidup yang telah mati, sehingga memungkinkan cendawan Aspergillus sp. untuk berkembang biak dengan baik (Nadhifah $e t$ $a l$. , 2016). Oleh karena itu dengan dilakukannya isolasi cendawan Aspergillus $s p$. diharapkan dapat mengetahui morfologi, jumlah koloni, kecepatan tumbuh serta kepadatan spora cendawan tersebut.

\section{METODOLOGI}

Penelitian ini dilaksanakan pada September 2019 sampai November 2019 di Laboratorium Perlindungan Tanaman, Jurusan Produksi Pertanian, Politeknik Negeri Jember. Kemudian untuk pengambilan sampel tanah dilakukan di dua lokasi sentra pertanian organik padi di Desa Lombok Kulon dan Desa Sulek, Kabupaten Bondowoso.

Alat yang digunakan dalam penelitian ini adalah cangkul atau sekop, wadah, plastik, Laminar Air Flow Cabinet (LAFC), cawan petri, erlenmeyer, pipet, tabung reaksi, gelas ukur, pipet volume, bunsen, pematik api, gelas objek, cover glass, mikroskop binokuler, Mikroskop connect komputer, hemasitometer, autoklaf, jarum ose, timbangan digital analitik, gunting, lakmus, hand counter, beaker glass, hand sprayer, kamera, kalkulator, hot plate dan magnetic stirer, sampel tanah dari masing-masing daerah, 
aquadest, $\mathrm{NaCl}$ fisiologis $0,85 \%$, lactophenol cotton blue, alkohol, alumunium foil, tisu, kapas, PDA instan, masker, alkohol, plastik polypropylene, kertas label, serta plastik wrap.

Metode penelitian yang digunakan adalah metode survey, yaitu dengan membandingkan cendawan Aspergillus sp yang dapat diisolasi dari 2 lahan yang berbeda. Data dari hasil penelitian yang diperoleh kemudian akan dianalisis secara kualitatif dan kuantitatif. Data kuantitatif dianalisi dengan perangkat lunak SPSS versi 15,0 , yang terdiri dari uji normalitas data (Kolmogorov-Smirnov), uji homogenitas data (One-Way ANNOVA) dan uji lanjut non parametrik menggunakan Paired Samples T Test.

\section{HASIL DAN PEMBAHASAN Morfologi Cendawan Aspergillus sp.}

Cendawan Aspergillus

$s p$. merupakan salah satu dari berbagai jenis cendawan yang dapat diisolasi dari alam. Umumnya cendawan Aspergillus sp. ini tersebar banyak di alam, baik di udara, tanah bahkan pada buah-buahan busuk (Fatmawati et al., 2018).

Tabel 1. Morfologi Cendawan Aspergillus sp.

Table 1. Morphology of Aspergillus sp.

\begin{tabular}{|c|c|c|c|c|c|c|c|c|}
\hline \multirow{3}{*}{\multicolumn{3}{|c|}{$\begin{array}{l}\text { Perlakuan/Sampel } \\
\text { Treatment/Sample }\end{array}$}} & \multicolumn{6}{|c|}{$\begin{array}{l}\text { Morfologi Cendawan Aspergillus sp. } \\
\text { The morphology of the fungus Aspergillus sp. }\end{array}$} \\
\hline & & & \multirow{3}{*}{$\begin{array}{c}\text { Warna } \\
\text { koloni } \\
\text { Colony } \\
\text { color }\end{array}$} & \multirow{3}{*}{$\begin{array}{l}\text { Bentuk } \\
\text { konidia } \\
\text { Conidia } \\
\text { form }\end{array}$} & \multirow{3}{*}{$\begin{array}{l}\text { Bentuk } \\
\text { vesikula } \\
\text { Forms of } \\
\text { vesicles }\end{array}$} & \multirow{2}{*}{$\begin{array}{c}\text { Bentuk } \\
\text { konidiofor } \\
\text { Conidiophores } \\
\text { form }\end{array}$} & \multirow{2}{*}{$\begin{array}{c}\text { Warna } \\
\text { konidiofor } \\
\text { Conidiophores } \\
\text { color }\end{array}$} & \multirow{2}{*}{$\begin{array}{l}\text { Struktur } \\
\text { Hifa } \\
\text { Hyphae } \\
\text { Structure }\end{array}$} \\
\hline & & & & & & & & \\
\hline \multicolumn{3}{|c|}{ S1L1 } & & & & - & - & - \\
\hline \multicolumn{3}{|c|}{ S2L1 } & - & - & - & - & - & - \\
\hline \multicolumn{3}{|c|}{ S3L1 } & $\begin{array}{l}\text { Hitam } \\
\text { Black }\end{array}$ & $\begin{array}{l}\text { Bulat } \\
\text { Round }\end{array}$ & $\begin{array}{l}\text { Bulat } \\
\text { Round }\end{array}$ & $\begin{array}{c}\text { Tidak } \\
\text { bercabang } \\
\text { Not branched }\end{array}$ & $\begin{array}{l}\text { Hialin (bening) } \\
\text { Hyaline (clear) }\end{array}$ & $\begin{array}{l}\text { Bersekat } \\
\text { Has a } \\
\text { bulkhead }\end{array}$ \\
\hline \multicolumn{3}{|c|}{ S1L2 } & - & - & - & - & - & - \\
\hline \multicolumn{3}{|c|}{ S2L2 } & $\begin{array}{l}\text { Hitam } \\
\text { Black }\end{array}$ & $\begin{array}{l}\text { Bulat } \\
\text { Round }\end{array}$ & $\begin{array}{l}\text { Bulat } \\
\text { Round }\end{array}$ & $\begin{array}{c}\text { Tidak } \\
\text { bercabang } \\
\text { Not branched }\end{array}$ & $\begin{array}{l}\text { Hialin (bening) } \\
\text { Hyaline (clear) }\end{array}$ & $\begin{array}{l}\text { Bersekat } \\
\text { Has a } \\
\text { bulkhead }\end{array}$ \\
\hline \multicolumn{3}{|c|}{ S3L2 } & $\begin{array}{l}\text { Hitam } \\
\text { Black }\end{array}$ & $\begin{array}{l}\text { Bulat } \\
\text { Round }\end{array}$ & $\begin{array}{l}\text { Bulat } \\
\text { Round }\end{array}$ & $\begin{array}{c}\text { Tidak } \\
\text { bercabang } \\
\text { Not branched } \\
\end{array}$ & $\begin{array}{l}\text { Hialin (bening) } \\
\text { Hyaline (clear) }\end{array}$ & $\begin{array}{c}\text { Bersekat } \\
\text { Has a } \\
\text { bulkhead }\end{array}$ \\
\hline \multicolumn{9}{|c|}{ Keterangan } \\
\hline S1L1 & & \multicolumn{7}{|c|}{ : Kedalaman 0-5 cm + Desa Lombok Kulon. } \\
\hline S2L1 & & \multicolumn{7}{|c|}{ : Kedalaman 10-15 cm + Desa Lombok Kulon. } \\
\hline S3L1 & & \multicolumn{7}{|c|}{ : Kedalaman 20-25 + Desa Lombok Kulon. } \\
\hline S1L2 & & \multicolumn{7}{|c|}{ : Kedalaman 0-5 cm + Desa Sulek. } \\
\hline S2L2 & & \multicolumn{7}{|c|}{ : Kedalaman 10-15 cm + Desa Sulek. } \\
\hline S3L2 & & \multicolumn{7}{|c|}{ : Kedalaman 20-25 cm + Desa Sulek. } \\
\hline$(-)$ & & \multicolumn{7}{|c|}{ : Cendawan Aspergillus sp. tidak ditemukan dan tidak teridentifikasi. } \\
\hline Note & & \multicolumn{7}{|c|}{ : } \\
\hline SIL1 & & \multicolumn{7}{|c|}{ : Depth 0-5 cm + Lombok Kulon Village. } \\
\hline$S 2 L 1$ & & \multicolumn{7}{|c|}{ : Depth 10-15 cm + Lombok Kulon Village. } \\
\hline$S 3 L 1$ & & \multicolumn{7}{|c|}{ : Depth 20-25 + Lombok Kulon Village } \\
\hline SIL2 & & \multicolumn{7}{|c|}{ : Depth 0-5 cm + Sulek Village. } \\
\hline$S 2 L 2$ & & \multicolumn{7}{|c|}{ : Depth 10-15 cm + Sulek Village. } \\
\hline$S 3 L 2$ & & \multicolumn{7}{|c|}{ Depth $20-25 \mathrm{~cm}+$ Sulek Village. } \\
\hline$(-)$ & & \multicolumn{7}{|c|}{ : The fungus Aspergillus sp. not found and not identified. } \\
\hline
\end{tabular}


Berdasarkan Tabel 1. dapat diketahui pada dua lokasi tempat pengambilan sampel tanah tersebut cendawan Aspergillus sp. dapat diisolasi. Lokasi pertama, yaitu Desa Lombok Kulon, cendawan Aspergillus sp. hanya dapat diisolasi pada kedalaman 20-25 cm dari permukaan tanah. Sedangkan pada lokasi kedua, yaitu Desa Tlogosari cendawan Aspergillus sp. dapat diisolasi pada kedalaman 10-15 cm dan 20-25 cm dari permukaan tanah. Menurut (Sagala et al., 2014), hal yang paling menunjang keberadaan cendawan Aspergillus sp. di dalam tanah adalah $\mathrm{pH}$ tanah. Cendawan biasanya dapat tumbuh dengan optimal pada kondisi $\mathrm{pH}$ tanah yang masam. Lokasi pertama memiliki nilai $\mathrm{pH} \pm 7$ (netral) dan pada lokasi kedua nilai $\mathrm{pH} \pm 6,6$. Berdasarkan kriteria $\mathrm{pH}$ tanah tersebut, masih belum optimal untuk mendukung keberadaan dari cendawan Aspergillus sp., sehingga menyebabkan beberapa level pengambilan sampel tanah tidak dapat ditemukan adanya cendawan Aspergillus $s p$.

Selain itu faktor lain yang menyebabkan tidak dapat diisolasinya cendawan Aspergillus sp. adalah kondisi kadar air tanah. Menurut (Muchtar et al., 2011), Aspergillus sp. merupakan tipe cendawan yang bersifat aerobik. Daerah persawahan Desa Lombok Kulon yang digunakan untuk pengambilan sampel tanah memiliki kondisi aerasi yang kurang baik, yaitu areal persawahannya cenderung terendam air. Berdasarkan hal tersebut tentunya akan membuat syarat hidup dari cendawan Aspergillus sp. tidak terpenuhi. Namun, aerasi di Desa Sulek lebih baik daripada di areal persawahan organik Desa Lombok Kulon sehingga pada beberapa level kedalaman pengambilan sampel tanah, cendawan Aspergillus sp. masih dapat diisolasi pada dua level kedalaman, yaitu pada kedalaman $10-15 \mathrm{~cm}$ dan $20-25 \mathrm{~cm}$ dari permukaan tanah.

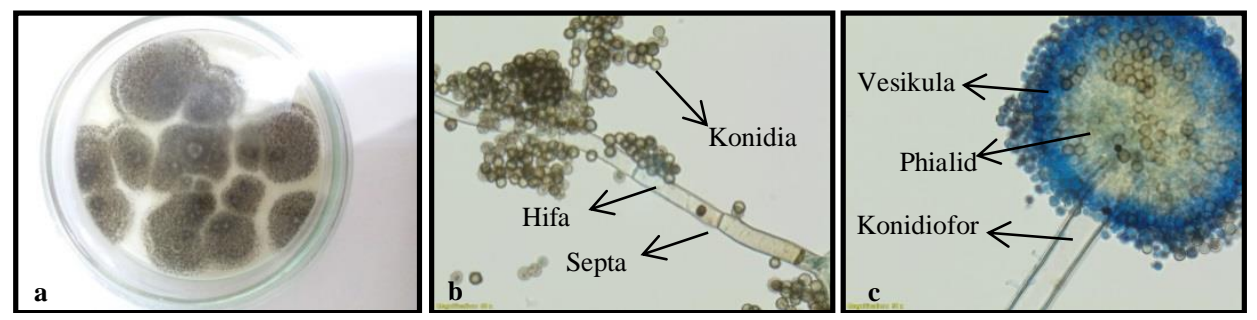

Gambar 1. Morfologi Cendawan Aspergillus sp. a) Koloni cendawan Aspergillus sp. secara Makroskopis. b) Struktur hifa dan bentuk konidia cendawan Aspergillus sp. (Perbesaran 100x). c) Tubuh cendawan Aspergillus sp.(Perbesaran 100x).

Figure 1. The morphology of the fungus Aspergillus sp. a) Aspergillus sp.

Macroscopically. b) The structure of the hyphae and the conidia of the fungus Aspergillus sp.(Magnification 100x). c) The fungal body of Aspergillus sp. (magnification 100x).

Berdasarkan Gambar 1a. Diatas, dapat diketahui bahwa ciri morfologi dari cendawan Aspergillus sp. yaitu memiliki warna koloni yang berwarna hitam. Hal tersebut sesuai dengan pernyataan (Praja, 2017) yang mengemukakan bahwa cendawan Aspergillus sp. memiliki koloni yang berwarna hitam. Selain itu cendawan Aspergillus $s p$. juga memiliki hifa yang bersekat (bersepta). Berdasarkan gambar 1b dapat diketahui bahwa struktur hifa cendawan Aspergillus sp. dapat diketahui bahwa hifa yang dimiliki oleh cendawan tersebut bercabang. Hal tersebut sesuai dengan yang dikemukakan oleh (Amaliyah, 2015), yang menyatakan bahwa hifa (miselium) yang terbentuk pada beberapa jenis cendawan termasuk juga 
pada jenis cendawan Aspergillus sp. biasanya memiliki bentuk hifa (miselium) yang bercabang.

Selain itu berdasarkan gambar $1 \mathrm{~b}$, dapat diketahui bahwa cendawan Aspergillus sp. memiliki konidia yang berbentuk bulat. Konidia merupakan salah satu organ reproduksi aseksual yang dimiliki oleh cendawan Aspergillus sp. Konidia juga biasa disebut sebagai spora. Mekanisme perkembang biakan secara aseksual dengan menggunakan spora diawali dengan spora Aspergillus sp. yang terbawa angin ataupun oleh binatang. Hal tersebut dapat terjadi karena konidia atau spora cendawan Aspergillus sp. ini bersifat kosmopolitan, dimana konidianya sangat ringan dan dengan ukuran yang cukup kecil, sehingga sangat mudah terbawa oleh angin (Tyasningsih, 2010).

Bagian lain dari cendawan Aspergillus sp., adalah konidiofor dan vesikula. Hal tersebut sesuai dengan pernytaan yang dikemukakan oleh (Natassya et al., 2013), yang menyatakan bahwa cendawan Aspergillus sp. memiliki konidiofor yang berbentuk batang. Pada Gambar 1c diatas, cendawan Aspergillus $s p$. memiliki bentuk konidifor yang tidak bercabang dan berwarna hialin (bening). Hal tersebut sesuai dengan pernyataan yang dikemukakan oleh (Mizana et al., 2016), yang menyatakan bahwa konidiofor pada cendawan Aspergillus sp. tegak dan tidak bercabang. Konidiofor pada berbagai jenis cendawan, termasuk juga konidiofor pada cendawan Aspergillus sp. berasal dari foot cell yang dimiliki oleh cendawan tersebut, dimana foot cell ini merupakan organ miselium pada cendawan yang berdinding tebal dan juga membengkak sehingga nantinya akan berkembang menjadi konidiofor. Kemudian dari Gambar 1c juga dapat diketahui bahwa bagian vesikula cendawan Aspergillus sp. berbentuk bulat. Hal ini sesuai dengan yang dikemukakan oleh (Hayani et al., 2017) bahwa cendawan Aspergillus sp. memiliki vesikula atau vesikel yang berbentuk bulat. Bagian vesikula juga terdapat phialid yang merupakan salah satu faktor penyusun dari vesikula. Hal tersebut sesuai dengan penyataan yang dikemukakan oleh (Praja, 2017), yang menyatakan bahwa pada bagian vesikula cendawan Aspergillus sp. tersusun oleh phialid.

\section{Jumlah Koloni}

Tabel 2. Jumlah Koloni Selama 7 Hari

Table 2. Number of Colonies for 7 Days

\begin{tabular}{lcc}
\hline & Lokasi & Rataan \\
Location & Average \\
\hline \multirow{4}{*}{ Keterangan } & Lombok Kulon & $2,7471 \pm 1,45284^{\mathrm{a}}$ \\
Note & Sulek & $13,2686 \pm 4,36095^{\mathrm{b}}$ \\
& berdasarkan uji lanjut Paired Samples T Test $(\mathrm{P}<0,05)$. \\
& $:$ Average figure that followed by a different letter indicates the value significantly different based \\
& on further test Paired Samples T Test $(P<0.05)$.
\end{tabular}

Berdasarkan Tabel 2 mengenai jumlah koloni selama 7 hari diatas dapat diketahui bahwa pada kedua lokasi tempat pengambilan sampel, yaitu di Desa Lombok Kulon dan Desa Sulek, jumlah koloni cendawan Aspergillus sp. yang dihasilkan menunjukkan berbeda nyata, dengan nilai rataan pada Lombok Kulon sebesar 2,7471 $\pm 1,45284^{\text {a }}$ dan 13,2686 \pm $4,36095^{\mathrm{b}}$ pada Desa Sulek. Hal itu menunjukkan bahwa jumlah koloni pada kedua lokasi tersebut terdapat perbedaan jumlah koloni yang signifikan atau berbeda 
nyata berdasarkan uji lanjut Paired

Samples T Test.

\section{Kecepatan Tumbuh}

Tabel 3. Kecepatan Tumbuh Cendawan Aspergillus sp. Selama 7 hari

Table 3. The velocity of Growing Aspergillus sp. For 7 days

\begin{tabular}{cc} 
Lokasi & Rataan \\
Location & Average \\
\hline Lombok Kulon & $2,1929 \pm, 72472^{\mathrm{a}}$ \\
Sulek & $2,2314 \pm, 47751^{\mathrm{a}}$ \\
\hline \multirow{2}{*}{ Keterangan : Angka rataan yang diikuti huruf yang sama menunjukkan berbeda nyata menurut Paired Samples } \\
Note $\quad$ Test $(\mathrm{P}>0,05)$. \\
: Average figure that followed by the same letter showed insignificant differences according to \\
the Paired Samples T Test $(P>0.05)$.
\end{tabular}

Berdasarkan Tabel 3 diatas mengenai nilai kecepatan tumbuh pada cendawan Aspergillus sp. dari kedua lokasi pengambilan sampel diketahui bahwa kecepatan tumbuh pada kedua lokasi tersebut menunjukkan berbeda tidak nyata berdasarkan uji lanjut Paired Samples T
Test. Sehingga dapat diartikan bahwa kecepatan tumbuh cendawan Aspergillus $s p$. pada kedua lokasi pengambilan sampel, yaitu di Desa Lombok Kulon dan Desa Sulek kecepatan tumbuh Aspergillus sp. yang berhasil diisolasi nilainya tidak berbeda nyata.

\section{Kepadatan Spora}

Tabel 4. Kepadatan Spora Cendawan Aspergillus sp. Selama 7 Hari

Table 4. The density of the fungus Aspergillus sp. For 7 days

\begin{tabular}{cc}
\hline Lokasi & Rataan \\
Location & Average \\
\hline Lombok Kulon & $2,2333 \pm 3,86825^{\mathrm{a}}$ \\
Sulek & $4,1333 \pm 3,58315^{\mathrm{a}}$ \\
\hline
\end{tabular}

Keterangan : Angka rataan yang diikuti huruf yang sama menunjukkan berbeda tidak nyata menurut Paired Samples $T$ Test $(\mathrm{P}>0,05)$.

Note : Average figure that followed by the same letter showed insignificant differences according to the Paired Samples T Test ( $P>0.05)$.

Berdasarkan Tabel 4 diatas dapat diketahui bahwa nilai kepadatan spora pada kedua lokasi pengambilan sampel tanah, yaitu di Desa Lombok Kulon dan Desa Sulek tidak menunjukkan perbedaan yang terlalu signifikan, sehingga berdasarkan uji Paired Samples T Test nilai kepadatan spora pada kedua lokasi tersebut berbeda tidak nyata.

\section{KESIMPULAN}

1. Ciri morfologis cendawan Aspergillus $s p$. secara mikroskopis, yang terdiri dari hifa yang bersekat, konidia bulat, konidiofor tegak dan tidak bercabang serta vesikula yang bulat.

2. Jumlah koloni cendawan Aspergillus sp. yang telah diisolasi dari kedua lokasi pengambilan sampel, dimana jumlah koloni cendawan Aspergillus sp. antara lokasi pertama dan lokasi kedua berbeda nyata.

3. Kecepatan tumbuh cendawan Aspergillus sp. yang telah diisolasi. Kecepatan tumbuh cendawan Aspergillus sp. antara lokasi pertama dan lokasi kedua tidak berbeda nyata 
4. Kepadatan spora cendawan Aspergillus $s p$. yang telah berhasil diisolasi. Kepadatan spora cendawan Aspergillus $s p$. pada kedua lokasi tidak berbeda nyata.

\section{DAFTAR PUSTAKA}

Amaliyah, N. 2015. Penyehatan Makanan 期 dan Minuman (1st ed.; A. Gunawan Tata, ed.).

Ariyono, R. Q., Syamsuddin, D., Lilik, S. 的 2014. Keanekaragaman Jamur Endofit Daun Kangkung Darat (Ipomoea reptans Poir.) Pada Lahan Pertanian Organik Dan Konvensional. Jurnal HPT, 2 (1), 19-28.

Fatmawati., Burhanuddin, R., dan Jayadi, 钢 M. 2018. Isolasi Dan Karakterisasi Cendawan Dekomposer Pada Bahan Kompos Jerami, Endapan Tanah Danau Tempe Dan Tanah Exfarm Pertanian Universitas Hasanuddin. Jurnal Ecosolum, 7 (2), 75-80.

Hasegawa, Y., et. al. 2007. Tensyuic 尌 Acids, New Antibiotics Produced by Aspergillus niger FKI-2342. Jurnal Chemical \& Pharmaceutical Bulletin, 55(9), 1338-1341.

Hayani, N., Erina. dan Darniati. 2017. 尌 Isolasi Aspergillus sp. Pada Paru-Paru Ayam Kampung (Gallus domesticus). Jurnal JIMVET, 1 (4), 637-643.

Mizana Khaira, D., Netty Suharti., dan E Arni, A. 2016. Identifikasi Pertumbuhan Jamur Aspergillus $s p$ pada Roti Tawar yang Dijual di Kota Padang Berdasarkan Suhu dan Lama Penyimpanan. Jurnal Kesehatan Andalas, 5(2), 355-360.

Muchtar, H., Kamsina., dan Indah Three, A. 2011. Pengaruh Kondisi Penyimpanan Terhadap Pertumbuhan Jamur Pada Gambir. Jurnal Dinamika Penelitian Industri, 22 (1), 36-43.
Murniasih, T. 2003. Metabolit Sekunder 㽬 Dari Spons Sebagai Bahan ObatObatan. Jurnal Oseana, XXVIII(3), 27-33.

Nadhifah Maulina, Yesy., Utami S.H., dan El Istamar. S. 2016. Isolasi, Karakterisasi, Dan Identifikasi Mikoflora Dari Rizosfer Tanah Pertanian Tebu (Saccharum Officinarum L.) Sebagai Bahan Ajar Kingdom Fungi Untuk Siswa Kelas X Sma. Jurnal Pendidikan, 1 (10), 2023-2030.

Natassya, G., Agung Suprihadi., dan MG EQ Isworo, R. 2013. Keanekaragaman dan Aktivitas Enzimatis Kapang Rizosfer Kacang Meongan (Aeschynomene americana L.) di Desa Sukolilo Barat, Kecamatan Labang, Kabupaten Bangkalan, Madura. JurnaL Biologi, 2 (3), 8-16.

Noerfitryani. 2018. Inventarisasi Jenis 钢 Jenis Cendawan Pada Rhizosfer Pertanaman Padi. Jurnal Galung Tropika, 7 (1), 11-21.

Praja Novita, R dan Aditya, Y. 2017. EQ Isolasi Dan Identifikasi Aspergillus spp Pada Paru-Paru Ayam Kampung Yang Dijual Di Pasar Banyuwangi. Jurnal Medik Veteriner, 1 (1), 6-11.

Sagala Astuti. W., Deni. E., dan Delvian. EQ 2014. Keberadaan Fungi Pelarut Fosfat Pada Tanah Bekas Kebakaran Hutan Di Kabupaten Samosir (The Existence Of Phosphates Solubilizing Fungi On Soil Of Forest Fire In Samosir Regency). 1-7.

Tyasningsih, W. 2010. Potensi Pakan Sebagai Sumber Pencemaran Aspergillus spp. Penyebab Aspergillosis pada Unggas. Jurnal Veterinaria Medika, 3(1), 31-34. 